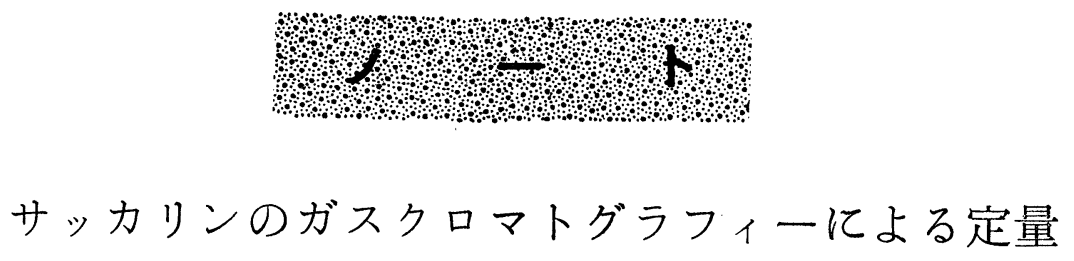

(昭和 49 年 9 月 17 日受理)

$\begin{array}{ccc}\text { 星 野庸二* } & \text { 鈴木敏 正* } \\ & \text { 菊池好則* } \\ & \text { 勢憲英* } & \text { 渡辺昭 宣* }\end{array}$

\title{
Determination of Saccharin by Gas Chromatographic Method
}

\author{
Youji Hoshino, Toshimasa SuzukI, Yoshinori KIKUCHI, \\ Norihide NOSE and Akinobu WATANABE
}

(Saitama Institute of Public Health: 639-1 Kamiookubo-higashi, Urawa, Saitama)

A method of the quantitative determination of saccharin in foods by gas liquid chromatography (GLC) was described.

Saccharin was methylated with dimethylformamide dimethylacetal (DMF-Me) heating for $30 \mathrm{~min}$ in glycerin bath at $110 \pm 5^{\circ} \mathrm{C}$. After reaction with DMF-Me, methyl derivative of saccharin obtained was determined by GLC equipped with a flame ionization detector (FID) and an electron capture detector (ECD). GLC was performed using DC-200 (10\%) on gas chrom $\mathrm{Q}$ as the column and $\beta$-BHC as an internal standard.

The recoveries of sodium saccharin added in various foods by the present method were $88.1 \sim 94.7 \%$, and the limit of detection as saccharin was about $0.02 \mu \mathrm{g}$ with FIDGLC and $0.02 \mathrm{ng}$ with ECD-GLC.

Furthermore, the determination with ECD-GLC was an effective method for the ultramicro-analysis.

(Received September 17, 1974)

\section{1. 緒言}

サッカリンを定量する方法としてガスクロマトグラフ ィ一（以下 GLC と略記）による方法は特異性, 検出感 度などの点で優れた方法であると考えられる。

現在, GLC による定量方法には, ジアゾメタン, ヨ ウ化メチルによるメチル化法 ${ }^{1), 2)}, N, O$-ビストリメチル シリルアセトアミドによる TMS 化法 ${ }^{3)}$, 亜鉛と塩酸に よる還元法 ${ }^{4}$ 小ょよび $N$-トリクロルメチルチオ誘導体法 $^{5)}$ などがある。

現在最も一般的で良好な結果を示すのはメチル化法で あるが，ジアゾメタン法はジアゾメタンの取り扱いにか なりの危険性があり, 市販品の入手は困難で試薬を合成 し，用時調製するといらことなどから簢便さに欠け，さ

* 埼玉県衛生研究所：埼玉県浦和市上大久保東 639-1
らにラクチム型に由来する副ピークを与える ${ }^{6)} . \quad \exists ウ$ 化 メチル法は試薬の保存にアンプルを要し, さらにメチル 化後に抽出操作が必要である.

今回, 著者らはジメチルホルムアミドジメチルアセタ ール（以下 DMF-Me と略記）を用いてサッカリンをメ チル誘導体とし，GLCによって直接定量する方法を検 討し, さらに種々の食品中のサッカリンナトリウムの定 量を試み，良好な結果を得た。

またメチルサッカリンは高い EC 能を有することか ら，ECD-GLC による超微量分析の基礎的条件について も検討を試みたので報告する.

\section{2. 実験方法}

2.1 試薬および標準溶液

i ）サッカリン標準溶液：サッカリン(東京化成 (株) 
製品をエタノールで再結晶したもの，融点 $\left.229^{\circ}\right) 200 \mathrm{mg}$ を精科し, 酢酸エチルに溶解して $2 \mathrm{mg} / \mathrm{ml}$ の溶液を調 製し，FID-GLC 用標準溶液とした。また，ECD-GLC 用標準溶液には FID-GLC 用標準溶液を酢酸エチルで 2 $\mu \mathrm{g} / \mathrm{ml}$ に希釈して用いた。

ii ） サッカリンナトリウム標準溶液：サッカリンナ トリウム（食品添加物用を $120^{\circ} て ゙ ~ 4$ 時間乾燥したもの） $500 \mathrm{mg}$ を精科し, 蒸留水を加えて $100 \mathrm{ml}$ とした。

iii) 内部標準溶液： $\beta-\mathrm{BHC}$ (残留農薬用標準品, 和 光純薬 (株)製) $200 \mathrm{mg}$ を精科し, 酢酸エチルに溶解し $\tau 2 \mathrm{mg} / \mathrm{ml}$ の溶液を調製し，FID-GLC 用内部標準溶 液とした。また，ECD-GLC 用内部標準溶液には FIDGLC 用内部標準溶液を酢酸エチルで希釈し， $2 \mu \mathrm{g} / \mathrm{ml}$ の 溶液として用いた。

iv) $N$-メチルサッカリン：東京化成(株) 製特級品.

v ） DMF-Me：東京化成 (株) 製

vi）酢酸エチル，無水硫酸ナトリウム，塩化ナトリ ウム，および硫酸はいずれも特級品 (和光純薬 (株) 製)を 使用した。

\section{2 装}

i ） ホモジナイザー：(株)日本精機製作所製.

ii ） バイアル：日電理化硝子(株)製，スクリューバ イアル (テフロンキャップ付).

iii）ガスクロマトグラフ：（株）島津製作所製， GC$5 \mathrm{AIFF}$ 型および GC-4BMPEE 型 $\left({ }^{63} \mathrm{Ni}, 10 \mathrm{~m} \mathrm{Ci}\right)$.

iv) カラム管：内径 $3 \mathrm{~mm}$, 長さ 1.5 または $2 \mathrm{~m}$, ガラス製.

\section{3 実 験 操 作}

\section{3 .1 試験溶液の調製}

試料 $25 \mathrm{~g}$ をホモジナイザーカップにとり, 水 $50 \mathrm{ml}$, $10 \%$ 硫酸 $5 \mathrm{ml}$, 塩化ナトリウム $20 \mathrm{~g}$, および酢酸エチ ル $100 \mathrm{ml}$ を加えて5 分間ホモジナイズした後, 内容物 を共セン遠沈管に移して遠心分離した。酢酸エチル層 $50 \mathrm{ml}$ を分液漏斗にとり，1\%硫酸 $10 \mathrm{ml}$ で洗浄し， 無水硫酸ナトリウムで脱水後溶媒を留去して, 残留物を 酢酸エチル $5 \mathrm{ml}$ に溶解して試験溶液とした。

また，直接酢酸エチルで抽出して液層がよく分離する 液状食品などでは酢酸エチルで抽出し，上記と同様の操 作を行った。 なお，ECD-GLC の場合は上記試験溶液を 10〜100倍に希釈して用いた.

\subsection{2 メチル化}

試験溶液 $1 \mathrm{ml}$ を正確にバイアルにとり， DMF-Me $0.5 \mathrm{ml}$ を加え, $110 \pm 5^{\circ}$ のグリセリン浴中に30分間放置 する. 反応後水冷して, 冷却した後, 内部標準溶液 $0.5 \mathrm{ml}$ を加える。

ECD-GLC 用試料は DMF-Me $50 \mu \mathrm{l}$ および酢酸エチ ル $0.45 \mathrm{ml}$ を加え, 上記と同様の操作を行った。

\subsection{3 検量線の作成}

サッカリン標準溶液 $0.1,0.2,0.4,0.6,0.8$, 拈よ

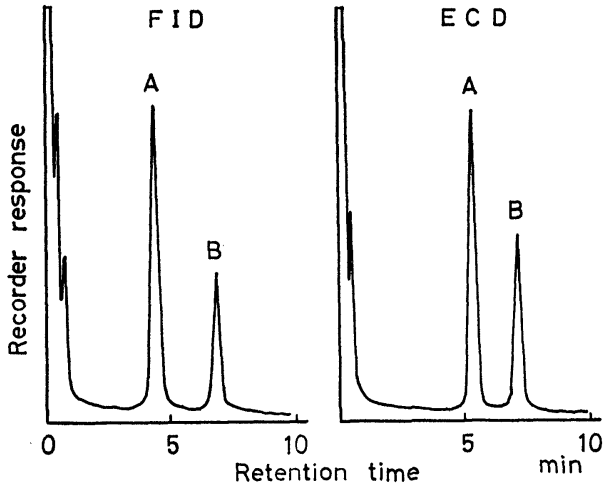

Fig. 1. Gas chromatograms of methyl saccharin $A$, methyl saccharin; $B$, internal standard ( $\beta$-BHC); column, $10 \%$ DC-200 (1.5 m $\times 3$ $\mathrm{mm}$ ); column temp., $200^{\circ} \mathrm{C}$ (FID), $190^{\circ} \mathrm{C}$ (ECD); injection port and detector temp., $210^{\circ} \mathrm{C}$; carrier gas, $\mathrm{N}_{2} 60 \mathrm{ml} / \mathrm{min}$ (FID), $65 \mathrm{ml} / \mathrm{min}$ (ECD).

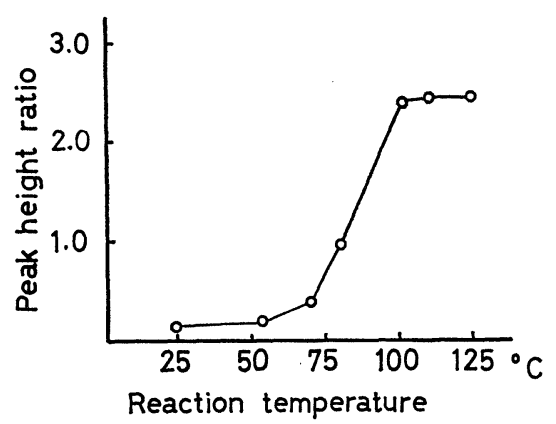

Fig. 2. Effect of reaction temperature on formation of methyl saccharin

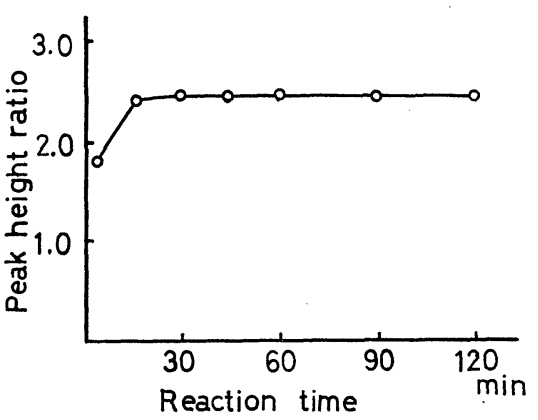

Fig. 3. Effect of reaction time on formation of methyl saccharin 


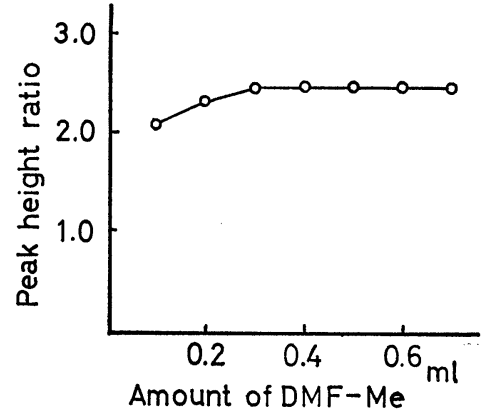

Fig. 4. Effect of amount of DMF-Me on formation of methyl saccharin

び $1.0 \mathrm{ml}$ ずつを, それぞれのバイアルにとり，酢酸エ チルを加えて $1 \mathrm{ml}$ とし, 前記 2.3.2 のメチル化操作を 行い，内部標準法によるピーク高比より検量線を作成し た。

また，ECD-GLC の場合は，ECD-GLC 用サッカリン 標準溶液を上記と同様の操作を行った.

\subsection{4 ガスクロマトグラフィーの条件}

(1) FID-GLC

カラム充てん剤および担体：10\% DC-200，ガスクロ $\triangle \mathrm{Q} \quad(80 \sim 100 \mathrm{mesh})$.

カラム管：ガラスカラム, $1.5 \mathrm{~m} \times 3 \mathrm{~mm}$.

カラム温度： $200^{\circ}$.

検出器执よび注入口温度: $210^{\circ}$.

キャリヤーガスおよび流量： $\mathrm{N}_{2}, 60 \mathrm{ml} / \mathrm{min}$.

感度： $10^{3} \mathrm{M} \Omega \times 0.32 \mathrm{~V}$.

(2) ECD-GLC

カラム充てん剤拈よび担体：10\% DC-200，ガスク口 ム Q $(80 \sim 100$ mesh $)$.

カラム管：ガラスカラム, $1.5 \mathrm{~m} \times 3 \mathrm{~mm}$.

カラム温度: $190^{\circ}$

検出器および注入口温度: $210^{\circ}$.

キャリヤーガス执よび流量: $\mathrm{N}_{2}, 65 \mathrm{ml} / \mathrm{min}$.

感度: $10^{2} \mathrm{M} \Omega \times 0.16 \mathrm{~V}$.

\section{3. 実験結果および考察}

\section{1 カラム充てん剤の検討}

充てん阂には $5 \%$ OV-17, $10 \%$ DC-200, $10 \%$ SE30 ，およ゙ $5 \%$ DEGS の 4 種類を用い，分離能および 検出感度について検討した。

OV-17，DC-200，SE-30，および DEGS のカラムと もメチルサッカリンの分離は可能であったが, DEGSの カラムは保持時間が長く, OV-17, DC-200, および SE-30のシリコーン系のカラムでは単一の良好な対称ピ 一クが得られ, 検出感度もほぼ同程度であった。この結 果, 本実験では DC-200 のカラムを用い, Fig. 1 に示 すようなメチルサッカリンのクロマトグラムが得られ
Table 1. Effect of Solvent on Formation of Methyl Saccharin

\begin{tabular}{l|c}
\multicolumn{1}{c|}{ Solvent } & Rate of reaction $(\%)$ \\
\hline Pyridine & 64.9 \\
Ethyl acetate & 98.7 \\
Methyl isobutyl ketone & 88.9 \\
Chloroform & 70.6 \\
Benzene & 99.1
\end{tabular}

Table 2. Reproducibility of Reaction

\begin{tabular}{|c|c|c|}
\hline $\begin{array}{l}\text { Saccharin } \\
\mathrm{mg} / \mathrm{ml}\end{array}$ & $\begin{array}{l}\text { Peak height } \\
\text { ratio }\end{array}$ & Statistics \\
\hline 0.10 & $\begin{array}{l}0.42 \\
0.47 \\
0.43 \\
0.46 \\
0.43\end{array}$ & $\begin{aligned} \bar{x} & =0.44 \\
\sigma & =0.019 \\
c & =4.38(\%)\end{aligned}$ \\
\hline 0.25 & $\begin{array}{l}1.24 \\
1.32 \\
1.21 \\
1.29 \\
1.30\end{array}$ & $\begin{aligned} \bar{x} & =1.27 \\
\sigma & =0.041 \\
c & =3.19(\%)\end{aligned}$ \\
\hline 0.50 & $\begin{array}{l}2.44 \\
2.55 \\
2.56 \\
2.48 \\
2.42\end{array}$ & $\begin{aligned} \bar{x} & =2.49 \\
\sigma & =0.056 \\
c & =2.28(\%)\end{aligned}$ \\
\hline 0.75 & $\begin{array}{l}3.74 \\
3.61 \\
3.86 \\
3.70 \\
3.79\end{array}$ & $\begin{aligned} \bar{x} & =3.74 \\
\sigma & =0.087 \\
c & =2.32(\%)\end{aligned}$ \\
\hline 1.00 & $\begin{array}{l}5.00 \\
5.12 \\
5.16 \\
4.98 \\
4.91\end{array}$ & $\begin{array}{l}\bar{x}=5.03 \\
\sigma=0.092 \\
c=1.83(\%)\end{array}$ \\
\hline
\end{tabular}

Coefficient variation $=\sigma / \bar{x} \times 100(\%)$

た.

\section{2 試験溶液調製方法の検討}

サッカリンナトリウムの抽出法としては, 酸性で塩化 ナトリウムを飽和し，酢酸エチルまたはェーテルを用い て抽出する方法, あるいは試料を透析した後, 溶媒抽出 する方法が広く行われている，本試験においては，清涼 
Table 3. Recovery Test of Sodium Saccharin in Various Foods

\begin{tabular}{l|c|c}
\multicolumn{1}{c|}{ Name of sample } & Level added (\%) & Recovery (\%) \\
\hline Cola & 0.02 & 94.0 \\
Cider & 0.02 & 94.7 \\
Fermented milk drink & 0.02 & 93.4 \\
Orange juice & 0.02 & 92.1 \\
Soybean paste & 0.04 & 88.9 \\
Soy sauce & 0.04 & 91.6 \\
Fish paste product & 0.04 & 90.9 \\
Boiled bean & 0.04 & 90.4 \\
Biscuit & 0.04 & 89.2 \\
Egg-apple pickles (mustard) & 0.04 & 90.3 \\
Ginger pickling in vinegar & 0.04 & 93.1 \\
Canned tuna & 0.04 & 89.8 \\
Wasabi preserved in sake lees & 0.04 & 88.1 \\
Marine manufactured product (codfish) & 0.04 & 90.6
\end{tabular}

飲料などの液状食品については酢酸エチルを用いて直接 抽出する方法を行った，乙かし，固型食品就よびしょう 油，又そなどの発酵食品では酶酸エチルを用いて直接抽 出すると土マルジョン化して分液しにくく，クロマトグ ラムにも妨害ピークが出現して，定量は不可能であっ た、そのため，試料を酢酸エチルととるにホモジナイズ し，さらに遠心分離することによりエマルジョン化する ことを防止した。

また，Daun ${ }^{2)}$ および蒔田ら ${ }^{5)}$ は酢酸エチル抽出液を 少量の水で洗浄する操作を行っている. しかし, 酶酸エ チル層を $10 \mathrm{ml}$ の水で 1 回洗浄すると約 $20 \%$ 程度, ま た，5\%塩化ナトリウム溶液 $10 \mathrm{ml}$ で 1 回洗浄すると 約 $10 \%$ 程度それぞれサッカリンの損失が認められたが， $1 \%$ 硫酸 $10 \mathrm{ml}$ で1回洗浄した場合ではサッカリンの 損失は認められず，さらに妨害ピークもほとんど除去さ れ定量することができた。このため本実験においては眽 酸エチル層を $1 \%$ 硫酸 $10 \mathrm{ml}$ で洗浄する操作を行った。

\section{3 メチ化反応条件の検討}

サッカリンのメチル化反応温度を上げると反応が促進 されることが考吕れるが，他方，逆にメチル誘導体が 分解されることも考元られる。 そこで反応温度を変えて メチル化操作を検討したところ，Fig. 2 に示すように $100^{\circ}$ ではメチルサッカリンの生成はほぼ平衡澾してい るが，若干のばらつきがでるので，本実験では反応温度 を $110 \pm 5^{\circ}$ とした。

次に反応時間について検討したところ，Fig. 3 に示 すように15分後汇はサッカリンのメチル化反応はほぼ $100 \%$ 近く進行するが，若干のばらつきがあるので，本 実験では反応時間を30分間とした。

メチル化剤の添加量によっても誘導体生成率の変動す ることが考兄られるので， DMF-Me 添加量を増加させ
て検討したところ，Fig. 4 に示すように $0.3 \mathrm{ml}$ 以上 でメチルサッカリンのピーク高は一定となり，この結果 本実験では DMF-Me 添加量を $0.5 \mathrm{ml}$ とした。また， ECD-GLC の場合は, DMF-Me 添加量が $30 \mu \mathrm{l}$ 以上で 一定のピーク高となったので，添加量を $50 \mu \mathrm{l}$ とした。

反応溶媒としてピリジン，酢酸エチル，メチルイソブ チルケトン，クロロホルム，执よびベンゼンの 5 種類を 用いて検討したところ，Table 1 亿示すように酶酸エチ ルおよびベンゼンでは良好な誘導体生成率を示したの で，本実験に拄いては反応溶媒として酶酸エチルを用い た。

以上のようにメチル化反応条件を検討した結果から， 前記メチル化操作を設定し，生成したメチル誘導体の室 温に扎ける経時変化を調べたところ，24時間放置後でも 何ら変化なく，安定性の高いことが認められた。

\section{4 メチル化反応率および再現性}

サッカリン $0.1 ， 0.25,0.5,0.75$, および $1.0 \mathrm{mg} / \mathrm{ml}$ の濃度についてそれぞれ 5 回ずつ反応率を調べた結果， 上記サッカリン濃度に各々対応する $N$-メチルサッカリ ン標準品のピーク高と比較して，98.3〜101.8\%であり， サッカリンは DMF-Me により定量的にメチル化されて いることが認められた。

また，この結果を用いて，内部標準物質に対するピー ク高比の再現性を求めたところ, Table 2 に示すように $\pm 4 \%$ 程度の誤差であり，良好な再現性を示した。

また，ジアゾメタンおよびヨウ化メチルによるメチル 化反応率を上記サッカリン濃度について比較 検討した ところ，ジアゾメタンによるメチル化反応率は99.1 $101.2 \%$ であり，再現性は土3\%程度であった。ヨウ化メ チルによる反応率は $96.4 \sim 100.7 \%$ であり，再現性は $\pm 5 \%$ 程度であった，以上のことから DMF-Me，ジアン゙ 
メタン，およびョウ化メチルによるサッカリンのメチル 化反応率は注添同じ結果であった。

\section{5 検 量 線}

前記実験方法 2 の項に打忛る検量線より，FID-GLC ではサッカリン濃度 $0.1 \sim 1.0 \mathrm{mg} / \mathrm{ml}$ の範囲で直線性を 示し, ECD-GLC では $0.1 \sim 1.0 \mu \mathrm{g} / \mathrm{ml}$ の範囲で直線性 を示した。

\section{6 保存料の影響}

各保存料の添加量として使用基準の最大值を採用し， ソルビン酸 $10 \mathrm{mg}$, デヒドロ酢酸 $2.5 \mathrm{mg}$, 安息香酸 3.0 $\mathrm{mg}$ ，サリチル酸 $1.5 \mathrm{mg}$, およびパラオキシ安息香酸エ ステル (エチル，プロピル，拈よびブチル) $2.5 \mathrm{mg}$ に ついてそれぞれサッカリン $1.0 \mathrm{mg}$ との共存下， 2.3 .2 のメチル化操作に従い，その影響を調べた。

この結果, ソルビン酸, デヒドロ酢酸, 安息香酸, 抒 よびサリチル酸については，妨害ピークが現れず，定量 性への影響は認められなかった。 パラオキシ安息香酸エ ステルについてはメチルサッカリンのピークの前後に 二, 三のピークが出現したが，定量性への影響は認めら れなかった。

ECD-GLC の場合では各保存料とも妨害ピークは現れ なかった。

\section{7 添加回収実験}

サッカリンナトリウム標準溶液 1 および $2 \mathrm{ml}$ (サッカ
リンナトリウムとして 5 および $10 \mathrm{mg}$ )を添加して回収 実験を行ったところ，Table 3 に示すような結果を得 た，液状食品では92.1 94.7\%，固形食品および発酵食 品では88.1〜93.1\%の範囲で回収された。

ECD-GLC の場合にもほぼ同様な回収率を示した。

\section{4. 結 論}

サッカリンをメチル化する方法において DMF-Meを 用いたことにより，反応後，直接 GLC 装置に注入でき ることから，他の方法によるメチル化法と比べ，メチル 化後の抽出操作を必要とせず，また DMF-Me の取り扱 いも簡単であるので，サッカリンを GLC によって定量 するときのメチル化法として有効であると考える.

\section{文献}

1) Grobel, W.: Z. Lebensmitt-Unters. u. Forsch., 129, 153 (1966).

2) Daun, R.J.: J. Assoc. Offic. Anal. Chem., 54, 1140 (1971).

3) Gerstl, R., Ranfft, K.: Z. Anal. Chem., 258, 110 (1972).

4) 黒田弘之, 広瀬秀雄: 食衛誌. 12, 322 (1971).

5) 蒔田政見, 山本重雄, 吉原恵子：衛生化学, 19, 297 (1973).

6) 食品添加物公定書第版解説書, B-366 (1973) 広 川書店. 